\title{
Social media as political hatred mode in Malaysia's 2018 General Election
}

\author{
Sara Chinnasamy ${ }^{\mathrm{a}, *}$ and Norain Abdul Manaf ${ }^{\mathrm{b}, *}$ \\ Universiti Teknologi MARA, 40450 Shah Alam, Malaysia
}

\begin{abstract}
In the era of technological advancement, with smartphones and digital devices, almost everybody can have access to the Internet. We move at very fast pace along with the information that we carry and every each of it will rapidly processed. Especially on social media platforms, where false news or scandals that revolve around pundits or the higher up often create chaos and triggers public interest. Malaysia had its $14^{\text {th }}$ General Election (GE14) dated $9^{\text {th }}$ May, 2018. It was believed to be the most nerve-wracking, fiercest general election to ever happen where after 61 years, Barisan Nasional $(\mathrm{BN})$ had to bow down to the voice of Malaysians where social media is part of the factor, utilised ultimately to influence the people and powerful enough to change people's perception, thus, create political hatred. A textual analysis was conducted on 187 news on six online news stations' social media platform during the 11 days of campaigning. In-depth interviews were also conducted to discover the political hatred issues on social media. The findings suggested issues like Goods and Service Tax (GST), candidates' reputations and 1 Malaysia Development Berhad (1MDB) scandal are the main causes of political hatred expressed on social media platforms.
\end{abstract}

Keywords: Malaysia, social media, political hatred, politics.

\section{Introduction}

Nowadays, Internet is an essential part of our daily life. With the emergence of new technology and evolution of the smartphones, people are more connected. As cited in Lenhart, Purcell, Smith and Zickuhr (2010), the usage of social networking sites (SNSs) among American young adults and teenagers has risen significantly since 2006 as it has become a social phenomenon among their peers (Yusop \& Sumari, 2013). Instagram, Twitter and Facebook are essential applications today as many of us have these apps for photo sharing and live update event. Every netizen is eagerly posting photos of their daily schedule, pictures of their pets, videos of attending events, course to show off luxuries and to express opinions on political topics happening in the country especially circa GE14. Social networking sites are built with micro blogging technology that supports blogging activity with smaller sizes of word posts and their users-friendly features invite wide usage among millennial (Yusop \& Sumari (2013), as cited in Chin and Yusop (2010). The current generation is so technology-savvy where in their research findings state that 90 percent of the respondents own various types of handheld telecommunication devices such as cellphones and i-Pad, and almost everyone own computers and utilise them for communication purposes. This statement is tally with previous facts that the root cause of the phenomenon is the smartphone penetration that drives more users to access the Internet than ever (Amirudin Abdul Wahab, 2016).

Social media is a place like the actual world which people share ideas, cooperating and collaborating to create art, encourage thinking and build commerce, start a debate or discourse, finding new friends, allies or even lovers which people have built several civilisations on (Mayfield, 2008). He added that, due to these reasons, it is spreading so quickly, not because of anything complicated but solely because of 'us', the society. This is because the revolution of technology that continue to create new ideas, services, business models and many more.

Millennials in Malaysia actively participates in social media activities, from entertainment to argument and even political discussion. Politicians or even non-politicians actively talk about the political topic. According to Malaysian Communications and Multimedia Commission (MCMC), the number of active users in Malaysia crossed the 20.1 million mark in 2015 , on the back of a $72.2 \%$ broadband penetration rate, and an estimated 16.8 million are also active social media users (Amirudin Abdul Wahab, 2016) whilst 18.3\% of the internet users shared their political view online.

\subsection{Social Networking Sites as a Political Platform}

As cited in Bennett (2014), Instagram is a platform for photo sharing and is increasingly popular and it doubles the users within a year as of March 2014 (Abel, Buff, \& Burr, 2016), as there were 200 million users on this social networking sites. A research done by the University of Missouri showed that majority of Instagram users are less likely to engage with political or controversial images (University of Missouri-Columbia, 2018). The research stated that many people view Instagram as an oasis to escape troubles and concerns of their lives, thus, they feel bad liking a photo of tragedy and prefers other sources for serious news.

\footnotetext{
${ }^{*}$ Corresponding author: sarachinnasamy@ outlook.com
} 
Twitter on the other hand is a useful platform for political communication, as the content of political tweet from politicians must be expressive than factual. Twitter has been the battleground for political actors and the place where scandal surrounding the politicians or the current environment can set in motion. It enables global communication immediate and unfiltered. Twitter has been quite the catalyst as it has become the way to connect directly with constituents and other interested audiences, dodging the traditional media (Sullivan, 2013).

Whilst, Facebook is actively used by political institutions for the purpose of entering into direct dialogs with citizens and encouraging political discussion in groups or pages in Facebook (Stieglitz \& Dang-Xuan, 2014). They added the use of Facebook is the most logical location for a discussion on political issues to an extent the discussion appears to have succeeded in the over-coming polarisation of online discussion that previously hard to be done (as cited in Kushin \& Kitchener, 2009). A research by Vitak et al. (2011) showed that undergraduate students tend to engage in lightweight political participation both on Facebook and also other platforms (Stieglitz \& Dang-Xuan, 2014). When people gather online, they tend to discuss issues of public interest as people share in such inter-connected society and if the issue is discussed by many, more users tend to join the bandwagon to keep up to date of what is going on. The topics usually get heated up especially when the general election is near. Malaysia's political arena has undoubtedly moved along with technology, thus, the usage of social media in political campaign become very crucial especially when the campaign season approaches.

\subsection{Problem Statement}

In the era of explosive growth of technology, social succumb to media influences teenagers' decisions to use drugs, no privacy, competition and peer pressure. As social media is so influential, there is no doubt that hot debated topics such politics is discussed through social media platforms which tally with Memon (2017). His article states that social media channels are now the main sources of news, opinions and debates among millennials. According to MCMC (2016), 18.3\% of the Malaysian Internet users share their political views online.

Political hatred is a common feeling among party supporters as they tend to believe that their party is superior to the other. Brooks (2015) stated that through anonymous hate, people could just post anything in this Internet age and scales up the ability to express political hate with astounding efficacy, as political hate is a demand-driven phenomenon and we are the one creating the platform for it.

Internet users cannot help but be bias on what they see on the social network due to political preferences. Thus, political hatred will move along with the ideology of the political parties or the politicians themselves. Political hatred may sound normal to many as people are joining the discussion, but the power that political hatred holds may sway the political parties as Malaysia is a multiracial country. Among the issue that has sparked political hatred is the 1MDB issue, implementation of GST, price hike of gas and many more. Netizens sure would not want to miss out on the issues that have been discussed internationally, as every Internet users have their 'two cents' to share. Thus, this study will explore the social media as the medium for political hatred in Malaysia and the exposure have led to findings that the social media is a platform for political hatred.

\subsection{Research Objectives}

The purpose of this qualitative research is to look at social media as the platform of political hatred in Malaysia. The objectives of this research are:

1. To explore the political hatred posts in Instagram, Twitter and Facebook.

2. To find out the Malaysian citizens response about political hatred on Instagram, Twitter and Facebook.

\section{Methodology}

This study utilises two approaches in qualitative research; (a) textual analysis, and (b) in-depth interviews. The interviews were conducted using an interview protocol among five (5) selected participants from different fields of expertise. For textual analysis approach, this study analysed 187 selected news on six (6) news agencies' Facebook, Instagram and Twitter during 11 days of campaign, namely Malaysiakini.com, Free Malaysia Today, Berita Harian, The Star and two international online newspapers, Bloomberg and The Straits Times Singapore. The news were selected based on the comments received on the articles, likes, re-tweets and shares. Comments related to issues, have sense of anger, sarcasm towards issues of the news were classified according to exploratory perspective in data analysis to code and theming by researchers. This study did not require a big sample because it is highly structured and the participants are consistently participating in social media activities and have to vote in GE14.

The in-depth interviews were conducted using semi-structured questions that were opinion-based and related to their experience and knowledge. The questions structured for these interviews revolve around their opinions about social media and political hatred in Malaysia and during the general election period, where the participants were asked about their direct and indirect involvement in sharing opinions online and seeing political hatred in social media platforms. Questions 
regarding the social media usage as other postings in the social media relating to political hatred and issues regarding Malaysian politics were discussed in detail during the interviews.

The understanding of these participants in political hatred would help lead to accurate findings. The participants were free to express their thoughts and view through open ended questions. Thus, that is why in-depth interview approach was adopted. The researchers believe this approach is important in determining the political hatred that have arisen from social media in Malaysia during this period. The researchers deem this could identify the causes of political hatred especially during the GE14 period, because each individual online or offline had their own beliefs, perspectives and viewpoints. Thus, the findings on political hatred especially on social media have found a big reversal for GE14. Both approaches used a thematic analysis to generate key themes.

This research has revealed the type of political hatred occurred in social media and getting the opinion from the people why political hatred happen during the GE14. The political parties have used multiple approach mediums in order to win the hearts of the people. It provides the explanation for winning and losing factor during the election and may become the source to overcome the factor for the upcoming election for both government and also opposition.

\section{Findings and Discussion}

GE14 saw the power of the people with the help of power of social media. Various issues and opinions were pointed out during the campaign and also through their manifestos. Foucault Theory suggested that power is not exactly a tool that were used by people but rather are actually the tools of power or simply power is a relation and embedded in the web of power relation (Wolf, 2013). Pastoral Power viewed as the power of an individual or simply productive power that produces subjects (English, 2004). She further added, "concept of pastoral power is an extension of disciplinary power and an alternative perspective to sovereign power that focuses on repression or having power over" as cited in Dreyfus and Rabinow (1982). Thus, Foucault's work helps to understand the rise of opposition power againts the previous government over the people. Hence, issues that highly mentioned both in textual and also during the interviews are explained next.

\section{Goods and Services Tax (GST)}

This issue was among the most debated topic from the moment it was informed to the public until today. It was supported at its initial stage, but also rejected by members of the society due to the concern of Malaysian economic capability. The concern by society was it will impact every level of society member as the amount charged by six percent $(6 \%)$. There is more middle income and below average income earners than people who can afford a hefty lifestyle. One of Pakatan Harapan (PH) manifesto for GE14 is to abolish GST and replace it with the old taxation system, the Sale and Services Tax (SST). The initiative of abolishing GST has brought many responses from social media during on the 11 days of campaigning, as many have hoped that $\mathrm{PH}$ to walk the talk as it was levied on most transactions since implementation in April 2015. It has caused a major debate among BN divergent as the idea was of Dato' Seri Najib Razak and the opposition party at that time held an assembly to protest against the implementation.

For Malaysians, GST as seen as a burden by according to Bakar and Sawandi (2018), 'isu ketidakpuasan GST masih mendapat tempat dalam kalangan rakyat yang cukup terasa kenaikan kos sara hidup' (dissatisfaction towards GST issue still flames among the society member who were affected by the significant increase of the cost of living). Thus, this issue continues to spark interest of Malaysian and highly debated among social media user and also recognised by the participants of this study. Bakar and Sawandi (2018) also added sokongan rakyat terhadap sistem GST telah semakin merosot selepas GST dilaksanakan, berbanding sebelum perlaksanaannya. Ini ditambah dengan sokongan terhadap kerajaan juga merosot dengan sangat banyak selepas perlaksanaan' (the society support for the GST system declined after it implementation compared to before the implementation. The support to the government also decreased drastically after GST was implemented). It cannot be denied that with the implementation of GST, it has jacked up the cost of living and are one of the major factors for political hatred on social media.

2. Candidates' Reputation and Promises

Globally, politics and scandals cannot be separated; it moves in a circle following one another. Politicians are always associated with political scandal as it is a way to put the politicians at loggerheads with others. Usually, they offer sweet promises to change voters' belief. According to Aragons, Palfrey and Postlewaite (2007), politicians make promises to secure themselves in the administration and assumed that candidates' reputation at every election can be either good or bad. Therefore, candidates with good reputation are the ones that never reneged in past elections, whilst the candidates with bad reputations are the people that break promises that they made.

Politicians in Malaysia actively take part in online community to reach out their supporters and the community. They gave opinions, share political belief, criticising other politicians and be part of the community in offline arena too. Online political participation by the society is when people look into how the political parties and the political leaders debate and also engage each other on political discourse; the public give opinions based on what has been circulated from the debated 
topic online. Thus, it is important for political parties and politician to be involved in debates and engagements as these will impact their reputation towards society's impression.

Therefore, the analysis focused on comparing the content of the news presented both in headlines and comment sections/replied tweets. Applied thematic analysis helped researchers to identify the presence of political hatred whilst helping readers to understand the issues being highlighted by netizens that led to political hatred. All six media platforms highlighted headlines about candidate's registration for polls on nomination day, which represented 21 out of 33 selected news (based on the words nominations, candidates and register). This is expected as it was the day stipulated by Election Commission (EC) for candidates to send their nomination forms. However, there were candidates who failed to comply with the nomination regulations. Generally, this issue can affect the credibility of the candidates, for example in Tian Chua's case which he was disqualified by EC for not fulfilling the requirement needed in order to contest as one of the qualified members of parliament (Suruhanjaya Pilihan Raya Malaysia, 2018). The Star Online Facebook had a page that shows the netizen backlashed him in Facebook commentary section (see Fig. 1).

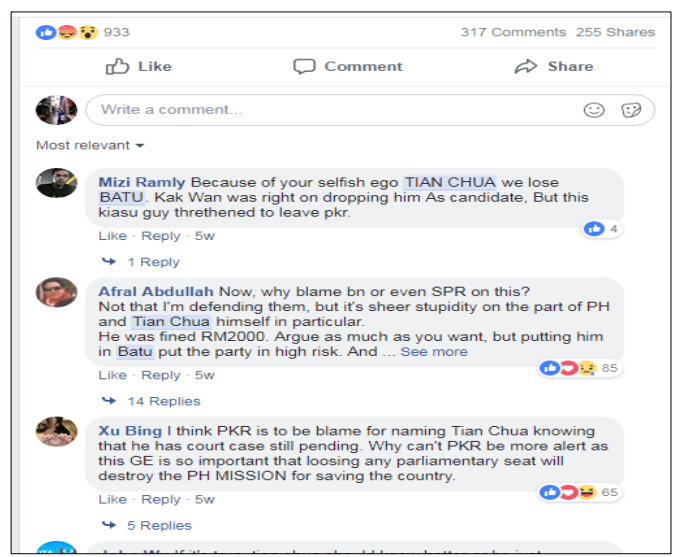

Fig. 1. Netizens' comments on Tian Chua disqualification.

The early campaigning stage saw that the selected news agencies reported mostly on what the political parties' leaders have to offer. For example, offering minimum wage to be raised if BN wins the election, continued development if BN were chosen, Malaysia stands to lose internationally if people vote for the opposition and few more. The chosen news mostly reported on BN's promises to the people. The responses given by the netizens were not as positive as the title proposed.
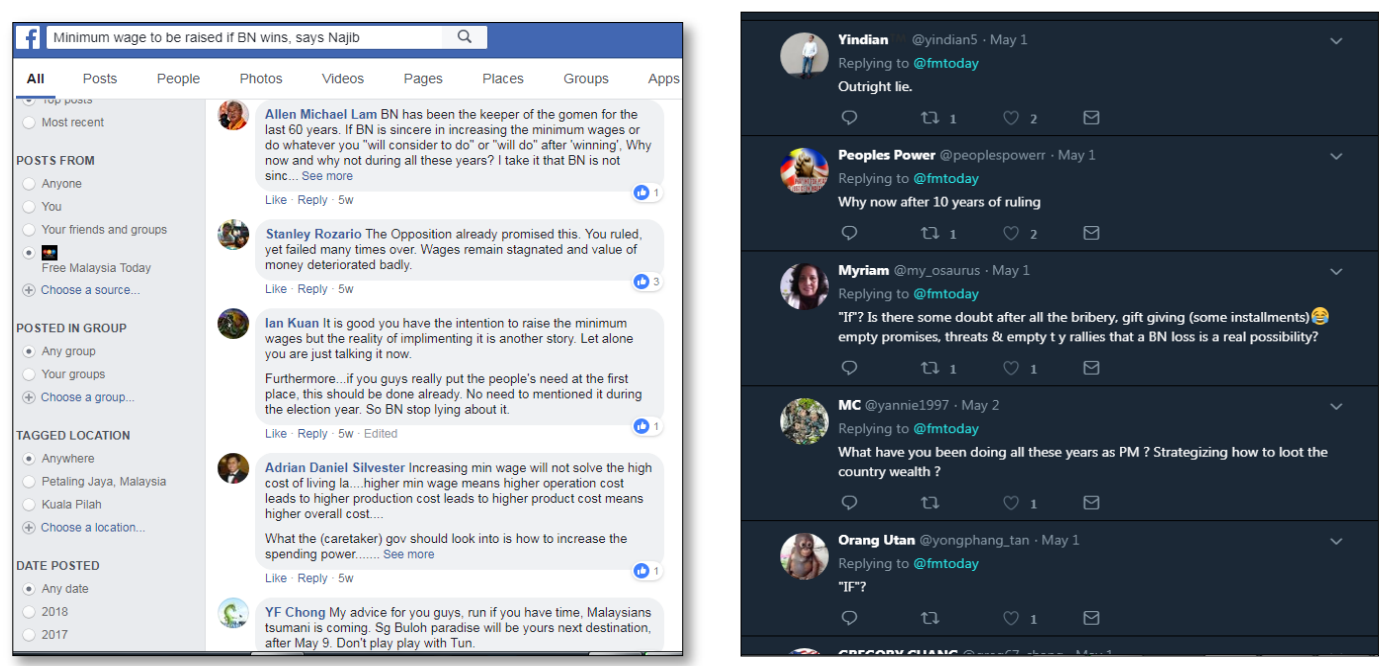

Fig. 2. Netizens' comments on minimum wages offered by the BN on Facebook (left) and Twitter (right).

The minimum wages offered by BN received unfavoured response from the social media users. This is aligned with the issue raised by Lo (2017) that the rising living cost does not match with the issue of minimum wages. The middle and low income consumers' were declining in terms of goods and services purchases that put a limit on Malaysia to become developed or high-income country and the wage inequality has widened and negatively impacting the national growth. The local talents had to compete with floods of foreign workers in order to secure a job. With minimum wages offered to foreign workers, employers prefer the latter as they had to pay more to them because of minimum wages regulations by 
the government. Thus, the issue of raised minimum wages sparks questions among the society, as the step should have been taken ages ago.

Promises of developmental projects were part of political agendas of the parties. To win over the people at the area, they usually make promises to the society of the area needed, such as education, access to any basic necessity such as marts, safe surrounding, etc. As for example, Free Malaysia Today (FMT) dated 29 $9^{\text {th }}$ April 2018 mentioned, “Amanah man promises to give Kamunting people a university" where there are already two universities in Taiping; Universiti Teknologi MARA (UiTM) and Universiti Teknologi Petronas (UTP). Thus, with the existence of a new university was said to raise interest among society to further their education. But promises on the developmental projects were not fulfilled, it merely just the candidate's way of gaining and piling trust to gain votes from society. Another example from FMT dated $3^{\text {rd }}$ May 2018, "Choose BN for continuous development, Salleh tells Semporna”. Felda in Segamat area also received a convincing offer where Subramaniam (MIC) showered Segamat Felda with RM 1 million replanting funds by polling day. Thus, making promises are sure one of the way to obtain votes from the people but also will become the main reason for the party to be criticised back if the promises failed to be fulfilled by the winning government.

Candidates' personal attacks were one of the popular counter attack modes in order to sway the people's attention and make themselves convincing. Personal attack may either bring a fruitful result to the political party or boomerang effect to the party. During the 11 days of campaigning, the technique was seen used multiple times by the candidates in order to sway people is trust and loyalty from the other candidates. The most popular candidates worth mentioning are Dato' Seri Najib Razak and Tun Mahathir Mohamad as they both contended for the prime minister position. A lot of attempts to downgrade the persona in order to influence people's perceptions, which not only happened to the two parties, but also to PAS candidates. They called out the opponents with many negative remarks or brought up scandals revolving around them, such as corruption (Najib's 1MDB scandal), spendthrift family member lifestyle (Tun Mahathir's grandchildren's fancy lifestyle, Rosmah Mansor's influence in Najib Razak decision making/massive spending), being obsequious and few more. Other example mentioned in Sarawak Report in 2016, "How Jho Low used 1MDB Cash to Fund Rosmah's Diamond Shopping Sprees”. However, Sarawak Report was banned from reporting on 1MDB in 2015. The ban was lifted after $\mathrm{PH}$ won the election.

\section{The Emerging Influence of Opposition Parties}

The opposition party role in politics is important to ensure a balanced political environment. It gives chances to the society to pick the party of their choice to govern the nation and also at the same time the public can give constructive criticism to the current ruling government. The power of the opposition can be seen in reports headlines such as, "Tok Batin: Semai Tribe Orang asli are completely rejecting BN for GE14", "Calon BN gigih pikat pengundi bandar", "Angry urban Malaysian chip away at PM Najib's dominance" and also "Ex-finance minister, Daim, campaigns for opposition". These headlines indicated that the preference towards opposition party was showing. The figure below shows the reactions and comments received from news headlines "BN loss will see bad future" which score amongst the highest interaction amongst netizen on selected news reported on May $2^{\text {nd }}$.
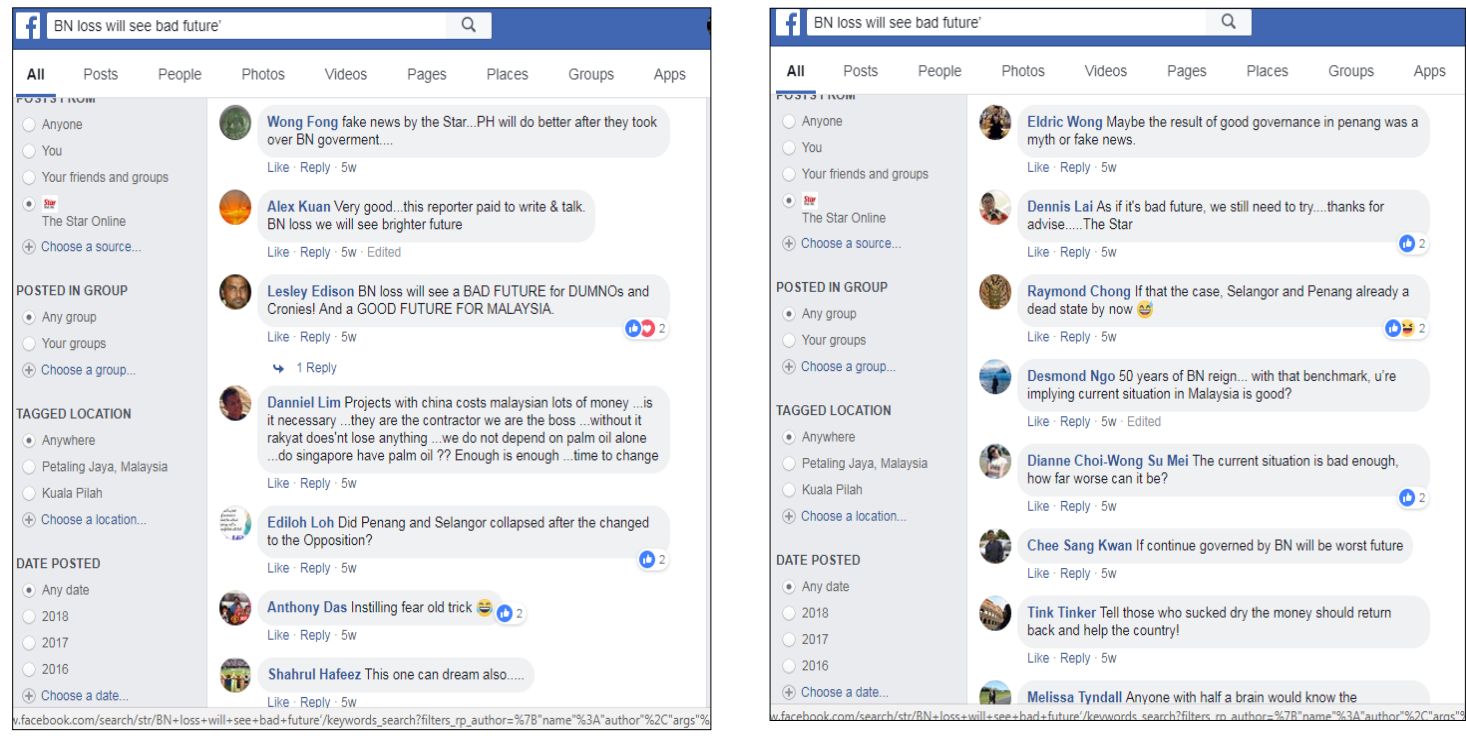

Fig. 3. Netizens' disagreement on The Star's article. 
Amongst the issues mentioned in the comment section by Facebook users were the influence of China's project in Malaysia and the state of Selangor and Penang (administration by DAP and PKR). Users also did not hesitate to criticise $\mathrm{BN}$ as the headlines indicated that Malaysia's future will be in uncertainty if BN not in charge. The influence of China's large infrastructure project in Malaysia began ever since Najib Razak became Prime Minister in 2009 where Malaysia has tilted decisively towards Beijing's orbit that saw 14 memorandums of understanding (MOUs) worth \$34 billion were signed under his watch (Capri, 2018). This statement is supported by Jennings (2018) where he stated that the opposition alliance suggest that Najib Razak has allowed too much of China's projects in Malaysia which usually relied on exports. These were the reasons that netizen were brave enough to point out their opinions.

At the final phase of campaign, the news showed the negative depiction of candidates, where they attack each other. They dissed each other's political movement that could be seen through news headlines such, "Sabah no longer 'fixed deposit' for Malaysian PM Najib, says party rebel Shafie Apdal" (The Straits Times, 6" May 2018), "Rafidah: Sacked from UMNO? I'm not a member of the kleptocratic organization" (Malaysiakini.com, 5 thay 2018), “They're bussing people in, claims Najib of large Harapan turnouts" (Malaysiakini.com, $5^{\text {th }}$ May 2018), "Gambar beribu hadir ceramah pembangkang palsu - Zambry" (Berita Harian, $5^{\text {th }}$ May 2018) and many more.

The news headlines in the newspaper depicted no issue or concern of the root of why political hatred happened. Apart from that, in the midst of political hectic, former Deputy Minister of Home Affairs, Nur Jazlan Mohamed was badly criticised by netizens due to his comment on "Overseas voters do not affect the GE14 result" in Malaysiakini.com. The article received many responses from netizen as shown as below:

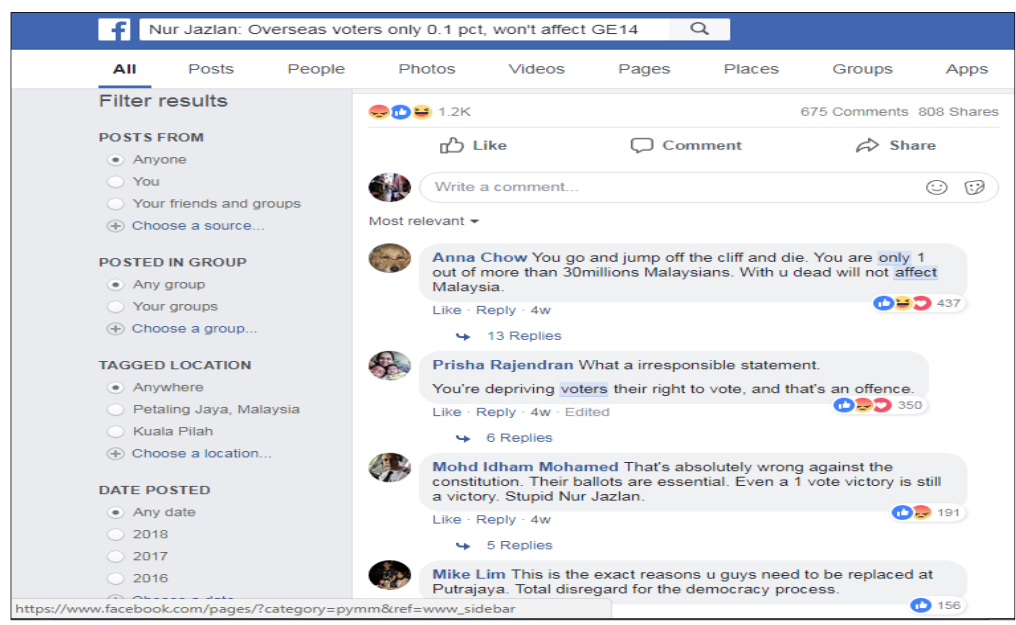

Fig. 4. Netizens' responses on Nur Jazlan's statement on Malaysiakini.com.

It is undeniable; his statement has sparked anger and hatred among netizens towards himself and also the political party that he represents. Thus, hatred comments on social media platforms can happen if it triggers the society with such situation, they questioned Nur Jazlan's statement of him denying the votes from the overseas voters.

\section{Mahathirism}

Mahathirism is an ideology that derived from thoughts and logical categories in achieving intellectual satisfaction and understanding. Mahathirism is believed to influence a lot of Malaysians preferably the younger voters as they feel only he can 'save Malaysia', considering a lot of outside influence in Malaysia's administrations. Mahathirism issue was mentioned in Malaysiakini.com (30 ${ }^{\text {th }}$ April 2018) (Najib: Here's Mahathirism for you-'his way or highway'), The Straits Times (30 ${ }^{\text {th }}$ April 2018) (PM: Dr. M's grab remark is typical Mahathrism, Malaysia election: BN communications chief says Mahathir trying to get sympathy votes) and Berita Harian ( $1^{\text {st }}$ May 2018) (Kita pilih Mahathir untuk tarik sokongan Melayu). Mahathirism is believed one of the thriving factors influencing the process GE14's 11 days of campaign. The Straits Times reiterated Mahathirism factor as it seen on international media portraying Tun Mahathir as one of the successful political icons. Tun Mahathir was keen in convincing Malaysians to vote for PH to save Malaysia. Ever since, the 'Save Malaysia' slogan was used expressively by social media user in Malaysia. The sign of strong authority and prioritising the community by becoming an ally with other opposition parties have made the party stronger in terms of "walk the talk', which can be retrieved from their "10 Janji 100 Hari PH" manifesto. The coalition managed to grab the attention of young voters and also his prime-time supporters. In Mahathirism ideology, it is over the individual, and a strong family-based society and it draws upon the experience of the western world in order to assess state and society considering modernity. For other political parties, Mahathirism is a mere autocratic administration and will ruin the 
country if they were to win. It is not only capable of swaying people's thoughts and mind but also can be a good tool for $\mathrm{PH}$ in winning the heart of young voters and existing Tun Mahathir supporters.

\section{Conflicts within and inter-political parties}

Political conflicts happen to every political party and it can happen either within the party or inter party. It happens because of differences in ideology and approaches that they want for the party. Some may focus on the prominence of the party and some parties prefer to have a 'save face/individual reputation'. During the 11 days of campaigning, a lot of conflicts happened, namely Nik Omar (Nik Aziz's eldest son who was known as a PAS leader) contending on behalf of PH's Parti Amanah Negara candidate that has caused a stir among PAS member and supporters, whilst his brother Nik Abduh was contesting as PAS candidate as reported by The Star (30 $0^{\text {th }}$ April 2018). According to Habibu (2018), "PAS led a bruising campaign against so-called "moderates" who were also called "Anwaristas" and "jebon (weasels)". These leaders then left PAS to form Amanah". Conflicts involving ex-member of UMNO/BN also mentioned as "UMNO defector shows up at Sungai Besar nomination centre in PH colours". A report by Straits Times (2 ${ }^{\text {nd }}$ May 2018), 'ExFinance Minister Daim campaigns for opposition" foresaw that Malaysian are taking sides on the opposition on social media as all the former ministers are turning their back from BN and joining the PH's force. The conflicts have brought consequences towards the party as the supporters come and go, and sustaining the trust of members of the party take the effort of the whole committee members as everyone has different opinion and views for the sake of the party.

\section{Preserved Malay Special Rights}

The Malays special rights in Malaysian constitution (Article 153) were also debated during the campaigning period, where Universiti Teknologi MARA (UiTM), known for 'Bumiputera only university' was mentioned by Dato' Seri Najib Razak. "Najib: Opposition has no agenda to safeguard UiTM interests" was mentioned in various newspapers including the researcher's selected newspaper. Due to the special privilege that was given to Bumiputera's, many supporters and political actor politicise the idea and make an argument out of it. Social media users have a different thought on the idea of opening UiTM to non-Bumiputera but some also opposed the idea as to preserve the Malay's special rights during the campaigning period.

The following interview transcriptions are the answers to Research Objective 2. The researcher had conducted an indepth interview with participants to explore their perspectives on the topic of political hatred on selected social media platforms. The transcription begins with descriptions of all the candidates namely Candidate N1 to N5. All informants are Malaysian based in Alor Setar and Kulim in Kedah, Shah Alam and Klang in Selangor and Kuala Lumpur, respectively. The participants' responses were tabulated in Table 1 as shown as below:

Table 1. Responses from the participants.

\begin{tabular}{cl}
\hline Name & \multicolumn{1}{c}{ Responses } \\
\hline $\mathbf{N 1}$ & It's challenging but competitive between Najib and Tun Mahathir. \\
$\mathbf{N} 2$ & I think the political situation of the GE14 campaign is so nerve-wracking. \\
$\mathbf{N 3}$ & It's a fierce competition, but we are already expecting the winning party. \\
$\mathbf{N} 4$ & It's a drastic political changes showing political maturity among Malaysians \\
& especially 40-43\% young voters. Social media was highly utilised for the purpose of \\
& electoral gates and electoral political discourses. \\
N5 & The election's campaign totally changed with the usage of Twitter, Instagram, \\
& Facebook, and Youtube.
\end{tabular}

The participants shared many commonalities in giving out rational opinion. The categories and themes derived from the in-depth interviews on the response on political hatred on social networking sites namely Facebook, Twitter and Instagram are listed.

\subsection{Political Strategies on Social Media}

Participation in social networking sites increases from day to day. Advancement of technology and digital communication has enabled society to share their life, and opinions and it has become a social norm in our society to share everything online. The political strategy on social media is gathered in three themes: (i) crucial political tools; (ii) the emergence influence of opposition; and (iii) opinion about politic on social media. These themes are derived from the $\mathrm{N}$ responses towards political strategy on social media. 
1. Crucial Political Tools

Conformity of social media as a political tool is one of the supporting factors in this study. The responses from the $\mathrm{N} 1$ in Malaysia were observed when they expressed on political hatred in selected social media platform during the GE14 campaign. Shim and Oh (2018) stated that as voters, people not only voice their opinion on social media but later establish political movements via political engagement and participation. All the $\mathrm{N}$ stated that social media is indeed crucial political role and their responses were restated below:

“Yes, it is." (N1)

“Of course social media plays a crucial role in political campaigns." (N2)

"Yes, social media is a very crucial platform for either government or opposition to reach out to the voters itself to find the latest current issues." (N3)

"I claim this year is a Facebook election year." (N4)

"As journalist, we follow the leaders and candidates. We opened the candidates' Twitter, the Instagram or Facebook on their activities. It's a new kind of campaigning." (N5)

Thus, it can be concluded from the participants feedback that social media is indeed a crucial tool for political campaign as it can help to the success of the campaign as people are very dependant of technology to reach out to others. It also helps journalists to monitor current activities of the political actors and parties without having to follow them around.

2. The Emergence Influence of Opposition

The opposition plays a very important role in order to maintain a healthy competition in politics. Below are the statements from the participants seeing the emergence influence of opposition in social media and the responses are stated below:

"People from PH were quite dominating compared to the BN. After the election, Ifollowed some PH politicians through social media. Although I follow Tun M's accounts, PH politicians were sensational in social media." (N1)

"I spend most of my time on social media in Twitter especially Muar's MP Syed Saddiq and Lembah Pantai MP, Fahmi Fadzil (both are PH representatives). They really dominated Twitter to tackle the younger voters." (N2)

“Opposition's Nurul Izzah, one of the new faces.” (N3)

“PKR, they are good bloggers. For examples, Rafizi Ramli and Tony Pua. They got the power to attract people.” (N5)

Based on the responses given by the participants, during the GE14 campaign, the opposition parties from PKR, Parti Pribumi Bersatu (PPBM), Parti Amanah Negara (PAN) and others, unite to form a coalition named Pakatan Harapan $(\mathrm{PH})$, dominating the social media platforms as the candidates are very popular offline as they have been vocal towards the previous ruling government. Nurul Izzah known for her more than decade-long involvement in politics since at a very young age. She has been actively involved in any march against the previous government along with Rafizi Ramli, who is a political influencer and other opposition politicians.

3. Opinion about Politic on Social Media

According to Shim and Oh (2018), people who share a high level of opinion congruence would feel more fear of isolation. Therefore, they tend to be anonymous online in expressing their opinion on political issues by using pseudonyms. They also added that the anonymity offered online enables individuals to do what they usually do not in reality (as cited in Suler, 2005). Yet, there are also groups of people that bluntly give their opinions online or joining the topic that attract their interests. The statements from the participants seeing the opinion about politic on social media and the responses are stated as below:

“It's better to preserve your vote from online discussion, and most important thing is, it's not healthy in social media and keyboard warriors." (N1)

"I do share my opinions, as I can hear and get other's feedback as well. But, I always have to keep in mind that I need to be neutral and not biased to any political parties." (N2)

"Yes, I participate in voicing out my opinion in social media which I feel the issue is breaking issue and there's something I must say about it." (N3) 
Participants had mixed feelings on social media as they have a preference on how they would share their opinion online. Sharing opinions online might not be in a serious issue like politics, given the strict law and political situation in Malaysia as the wall to freedom of speech.

\subsection{Political Hatred on Social Media}

The responses were observed and for the researchers to understand the sense of political hatred that happens on social media among Malaysian through online news portal. Political hatred is common in political topics as one has a different opinion from another and stand to disagree on it. It could be mild or can get so excessive which sometimes leads to an unexpected situation. The statements from the participants seeing the opinion about political hatred on social media and the responses are stated as below:

\section{Political Hatred among Malaysian}

"Hatred is more to the arguments between political parties and supporters. Their online manners ridiculously to accept." (N1)

"Political hatred happens when you are too obsessed with one political party or individuals that you can't accept other's views. There many political hatred messages on social media and people even get paid by certain parties or individual to spread hate messages online." (N2)

"Political hatred is common in any nations it just that the constituencies need to be smart in justifying what issue were raise by the political parties as is it for the sake of putting politicians at loggerheads with one another. Political hatred issue during election week prone to cyber troopers who is driven by the government towards the opposition where the attack by the cyber troopers towards the opposition was very intense." (N3)

Participant N1, N2 and N3 believed that political hatred among social media users could go to the extent that cyber troopers and use pseudonyms to attack the opponent take the opposition or government. On the other hand, N4 believe that:

"Political hatred previously was raise by the PH where there was defamation factor. They used to attack opponent leaders also political parties. Social media played an important role in displaying the political events indirectly raised online political participation and debates on political discourses".

Hence, political hatred comes from disagreements on political beliefs and supporters on social networking sites, either the group supporting the opposition or the government. As supported by N1, N2 and N3 statements, it can be said that party attached supporters were likely to spark the political hatred itself.

2. Harsh and Hatred Opinion

Malaysians are known for their humility. Yet on social media, it seems that Malaysians are also very bold and harsh at expressing opinions particularly on political topics. This statement is supported by Shim and Oh (2018) where they stated, "Even political underdogs or minorities can cause their voices to be heard on social media." and it could continue offline. The statements from the participants seeing the harsh responses of Malaysian on social media and the responses are stated below:

"I go through one or two on the above replies under one post. It's so hard for me to scroll down to read one by one. They are more than daring due to the freedom of expression, the accessible social media, and public manners beyond the line." (N1)

"Social media is their space freedom of speech." (N2)

“Due to social media, the whole Malaysia system is different now. It is also people's power." (N5)

Thus, it can be concluded that Malaysians are very prone to hatred comments on social networking sites as Shim and Oh (2018) stated that anonymity setting of individual online predicted that the use of social media is for political engagement. Chinnasamy (2017) claimed that social media had increased the online political participation among Malaysians through her two cases of Malaysian election previously.

3. Issues that Triggered Political Hatred

The main aim of this research is to look issues that triggered political hatred among Internet users namely in Twitter, Facebook and Instagram. The participants were asked what issues had triggered Malaysians the most and issues that also raise political hatred among netizens. The statements from the participants and the responses stated as below:

"The most political hatred issue is Najib's scandals and his wife. It will invite political hatred easily, and politicians also do spread the hatred including 1MDB issues." (N1) 
" $1 M D B$ and the rise cost of living are the most important issues during GE14. There are thousands of tweets and post by Malaysians!” (N2)

"The issue that highly debated on social media would be GST and 1MDB because these issues have been prolonging until the Election Day without solution." (N3)

"One of the issues is GST. The GST issue somehow been played by the opposition to gain voters attention in their 100 days of promises. It attracted the people to vote for the opposition." (N4)

"People are angry at Dato' Seri Najib. IMDB and GST were created by the opposition now the current government to gain people attention." (N5)

It can be concluded that the political hatred was derived mainly from GST and 1MDB issues. Other matters such as candidates' reputation, Mahathirism, cost of living (which leads back to GST) are among the main topic that triggered the netizen as stated by all the participants. The participants stated that the issues triggered social media users because:

"It was considered as sensitive issues for the people." (N1)

"The youth are the largest group of voters that been effected by GST and the cost of living. Most of the middle-income group, living in the city, doesn't benefit most of the past government initiatives to help the people. They are really desperate for their voices to be heard. By talking about it on social media, it will at least get the opposition attention." (N2)

"It involves public fund, $1 M D B$ where the government misuse the fund to afford projects that involved corruption, the GST implementation itself basically not fair and only benefitted the government." (N3)

"The politicians should become the role model to the society. They have to respond very fast to certain issue it's very hard to control people perception." (N4)

The 1MDB issue is regarded as a factor for the rise of political hatred among social media users and also participants of the study. As 1MDB involves a public fund and people were informed on it, thus, when the scandal of money laundering by the organisation was exposed by $\mathrm{PH}$ it triggered public scrutiny both on social media and offline.

\section{Conclusion}

This research has successfully reached its objectives of exploring the political hatred on social media during Malaysian $14^{\text {th }}$ General Election. Through the textual analysis of 187 news and in-depth interview with participants, it looked into the opinions and feedback from students, executives, government servants and political analysts. The interviewees have expressed opinions on political hatred on social media. In general, they all agreed that social media is an important tool during election campaigning. The emerging influence of the opposition on social media is seen as a supporting factor for political hatred among supporters.

Social media is such a powerful tool that even experts in any field cannot deny it capability whether it brings bad or good impact, as it powerful enough to bring you down and cogent enough to bring you to the state of euphoria. It is a very essential tool for sharing and disseminating information. It eases the information to flow faster than traditional medium such as print and broadcast media. In the state of technological advancement, it is also being used in political activities where politicians or political parties all over the world use this medium to reach out to their constituents. It is also a platform where political hatred spreads very fast as social networking sites developer always improves their applications features for their users to share information, pictures, videos and many more. It is a good move to provide easier and handier functions to the applications but at the same time, they cannot control the content posted by users unless reported by other users. As information travels fast, constituents or social media users should be smart enough to judge the issues rose from political hatred matters.

Political hatred not only happens because of political disagreement, but the nature of not being able to accept other people's points of view and also the unheard voices of the society members. Fear of isolation from political participation also could be the contributing factor to political hatred where the minority joining the bandwagon for the sake of a dominant influence. Political disagreement should be discussed to create a healthier political environment. The differences in opinions can help one another to achieve a better development for the nation and also create a better society. Thus, through power theory, it has shown that the opposition of the government over the people where the struggles of question status of the people where they assert the right to be different whether in having opinion or freedom in expressing their thoughts. There have been a lot of discussions by the participants on the political hatred and why the issues spark political hatred towards the politician or parties. There lots of knowledge and thoughts shared that can help to give more 
perspectives on political hatred that occurs on social networking sites. This study has given a clearer idea and perspectives that has helped researchers to point out the surfaced themes based on the analysed comments on selected social media platforms. Researcher was overwhelmed by the thorough explanation by participants and their willingness to give opinion.

\section{References}

Abel, J. P., Buff, C. L. \& Burr, S. A. (2016). Social Media and the Fear of Missing Out: Scale Development and Assessment. Journal of Business \& Economic Research, 14(1), 33-44.

Aragonès, E., Palfrey, T. \& Postlewaite, A. (2007). Political Reputations and Campaign Promises. Journal of the European Economic Association, 5(4), 846-884.

Bakar, A. S. \& Sawandi, N. (2018). Impak Sebelum dan Selepas Perlaksanaan GST di Negeri Kedah. $4^{\text {th }}$ Annual ECoFI Symposium 2017, 1-10. Alor Setar: Pusat Pengajian Ekonomi, Kewangan dan Perbankan.

Brooks, A. C. (2015). The Thrill of Political Hating. Retrieved from The New Yorks Times: https://www.nytimes.com/2015/06/08/opinion/the-thrill-of-political-hating.html

Capri, A. (2018, May 10). Why Malaysia's Suprise Election Result Should Be a Wake-up Call for Global Leader. Retrieved from Forbes: https:/www.forbes.com/sites/alexcapri/2018/05/10/why-malaysias-suprie-election-resultshould-be-wake-up-call-for-global-leaders/

Chinnasamy, S (2017). New Media Political Engagement and Participation in Malaysia. Routledge.

Amirudin Abdul Wahab (2016). Creating a safer cyberspace for future digital natives. Retrieved from The Star Online: http://www.thestar.com.my/tech/tech-opinion/2016/06/24/creating-a-safer-cyberspace-for-future-digital-natives/

English, L. M. (2004). Foucauldian pastoral power and feminist organizations: A research direction for adult education. Sheffield, England: SCUTREA $34^{\text {th }}$ Annual Conference, University of Sheffield.

Habibu, S. (2018, April). Nik Aziz sons to contest in opposing camps. Retrieved from The Star Online: https://www.thestar.com.my/news/nation/2018/04/28/nik-aziz-sons-to-contest-in-opposing-camps/

Harun, N. M., Hamid, N. A., Yahya, M., Ahmad, B. \& Ismail, M. I. (2017). The Effects of GST Knowledge Towards Students' Spending Pattern. e-Academia Journal, 6(1), 116-126.

Jennings, R. (2018). How Malaysia became a 'model' for China's Overses Economic Expansion. The Forbes.

Lo, A. (2017). Salary increment cannot match rise in cost of living. Retrieved from The Star Online: https:/www.thestar.com.my/metro/views/2017/03/31/salary-increment-cannot-match-rise-in-cost-of-living-localscontinue-to-get-low-wages-due-to-presenc/

Malaysian Communications and Multimedia Comission (2016). Internet Users Survey 2016. Retrieved from Malaysian Communications and Multimedia Comission: https://www.mcmc.gov.my/skmmgovmy/media/General/pdf/IUS2016.pdf

Mayfield, A. (2008). What is Social Media? Retrieved from iCrossing: www.icrossing.com/insight_pdf_files

Memon, S. (2017). How Millennials and Social Media Changed The World. Retrieved from HuffPost: https://huffingtonpost.co.uk/shaz-memon/how-millennials-and-socia_b_15537484.html

Palil, M. R. \& Ibrahim, M. A. (2011). The Impacts of Goods and Services Tax (GST) on Middle Income Earners in Malaysia. World Review of Business Research, 1(3), 192-206.

Shim, K. \& Oh, S.-K. (2018). Who creates the bandwagon? The dynamics of far of isolation, opinion congruency and anonymity-preference on social media in the 2017 South Korean presidential election. Computers in Human Behavior, $86,181-189$

Stieglitz, S. \& Dang-Xuan, L. (2014). Social Media and Political Communication - A Social Media Analytics Framework. Springer-Verlag. 
Sullivan, S. (2013). What Twitter has meant for politics (and what it hasn't). Retrieved from The Washington Post: https://www.washingtonpost.com/news/the-fix/wp/2013/03/21/what-twitter-has-meant-for-politics-and-what-ithasnt/?utm_term=.3061f030ba47

Wolf, S. (2013). Climate Politics as Investment: From Reducing Emissions to Building Low-carbon Economies. Springer Fachmedien Wiesbaden, 1-11.

Yusop, F. D. \& Sumari, M. (2013). The Use of Social Media Technologies among Malaysian Youth. Procedia Social and Behavioural Sciences, 103, 1204-1209. 